\title{
Synthesis, Characterization, Thermal Studies, and Molecular Structure of New Metal Complexes of Dehydroacetic Acid Hydrazone
}

\author{
Tahani I. Kashar \\ Department of Chemistry, Faculty of Science, \\ Menoufia University, Shebin El-Kom, Egypt \\ Current address: Department of Chemistry, \\ Faculty of Science, Qassim University, Saudi Arabia

\section{Amal H.El-Sehli} \\ Department of Applied Chemistry, Faculty of Applied Science, \\ Taibah University, Madina Monawara, Saudi Arabia
}

doi: 10.19044/esj.2016.v12n3p266 URL:http://dx.doi.org/10.19044/esj.2016.v12n3p266

\begin{abstract}
Metal complexes of dehydroacetic acid hydrazone are synthesized and characterized by physical, chemical, and spectral studies. The ligand behaves as monobasic tetradentate coordinated with the metal ions through $\mathrm{C}=\mathrm{O}$, deprotonated phenolic oxygen, and azomethin nitrogen. The characterization data suggests a square planar geometry for $\mathrm{Cu}(\mathrm{II})$ complex and an octahedral geometry for all other complexes. The crystal and molecular structure of the $[\mathrm{Cu}(\mathrm{HL})] \mathrm{Cl} . \mathrm{H}_{2} \mathrm{O}$ complex has been established by a single crystal maXus. The thermal studies of the complexes showed that the decomposition takes place through four steps.
\end{abstract}

Keywords: Metal Complexes, IR, uv, single crystal, thermal studies, Synthesis

\section{Introduction}

Dehydroacetic acid DHA (3-acetyl-4-hydroxy-6-methyl-2H-pyran-2one) and enaminone containing 4-hydroxy-2-pyrone ring are often investigated compounds due to their use in the synthesis of organic compounds and their good complexing properties. Furthermore, studies have shown that such compounds and their complexes have very interesting biological properties (Chalaca, 2002; Lim, 2007; Ponnurengam, 2007; Viana, 2003; and Won, 2005). Synthesis and characterization of Ru(II) and $\mathrm{Ru}$ (III) complexes of a hydroxypyrone ligand, namely dehydroacetic acid were explored in their biological activities such as DNA-binding and 
antibacterial activity (Tan, 1984). Tri- and quadri-dentate schiff bases resulted from the reaction of dehydroacetic acid with diamines, aminoacids, aminophenols, and aminoalcohols. Also, copper(II), nickel(II), and palladium(II) chelates have been synthesized. The copper(II) complexes of bidentate Schiff bases of dehydroacetic acid with anilines have been prepared and characterized by electronic, IR, and NMR spectral measurements and magnetic moments (Tan, 1984). Co(II, III), Ni(II), and $\mathrm{Cu}(\mathrm{II})$ complexes of dehydroacetic acid $\mathrm{N}_{4}$-substituted thiosemicarbazones have been studied and characterized (El-Saied, 2003). The crystal and molecular structure of the four-coordinate $\mathrm{Cu}(\mathrm{II})$ complex, [Cu(DAhexim$\mathrm{H}) \mathrm{Cl}$ ] have been determined by a single crystal X-ray diffraction (El-Saied, 2003). 3-(1-tryptaminoetylidene)-6-methyl-2H-pyran-2, 4(3H)-dione (HL) has been synthesized (Marina, 2004) by the reactions of tryptamine with dehydroacetic acid (DHA). The molecular and crystal structure as well as the NMR data of the ligand has shown that the condensation of DHA and tryptamine occurs at acetyl-carbonyl and not at the pyrone-carbonyl group. Ruthenium(II) carbonyl complexes of dehydroacetic acid thiosemicarbazone have been characterized by physiochemical and electrochemical methods. The antimicrobial activity of these complexes in terms of their growthinhibition capacity against Gram +ve and Gram -ve bacteria and fungus have been discussed (Venkatachalam, 2005; Kumar, 2007; Kannan, 2007; Sivagamasundari, 2007). Therefore, the aim of this study was to synthesize and characterize the solid complexes of a ligand derived from ethylenediamene and dehydroacetic acid in molar ratio (1:2). Hence, these have biological activity and studies of thermal behavior of these complexes.

\section{Experimental Study}

\subsection{Materials and Methods}

All compounds and solvents used were pure chemicals from BDH or Aldrich, and were used without further purification. Elemental analyses (C, $\mathrm{H}, \mathrm{N}$ and $\mathrm{Cl}$ ) were carried out at the microanalytical Unit of Cairo University. Metal ions were determined using atomic absorption with a Perkin Elmer (model 2380) spectrophotometer. The IR spectra were measured as $\mathrm{KBr}$ discs using a Perkin-Elmer 1430 infrared spectrometer $\left(4000-200 \mathrm{~cm}^{-1}\right)$. Electronic absorption spectra in the 200-900 $\mathrm{nm}$ regions were recorded on a Perkin-Elmer 550 spectrophotometer. The magnetic susceptibilities were measured at room temperature using the Gouy method with mercuric tetrathiocyanatocobaltate(II) as the magnetic susceptibility standard. Furthermore, diamagnetic corrections were made using Pascal's constants (El-Table, 1996). A Bibby conductimeter $\mathrm{MCl}$ was used for conductance measurements. The crystal and molecular structure of copper complex by diagrams and calculations were performed using maXus (Bruker 
Nonius, Delft \& MacScience, Japan). However, this was aimed to establish its three dimensional structure (Table 4). The thermal analyses (DTA and TGA) were carried out on a Shimadzu DT-30 and TG-50 thermal analyzers in the $27-700^{\circ} \mathrm{C}$ range at a heating rate of $10^{\circ} \mathrm{C} \cdot \mathrm{min}^{-1}$.

\subsection{Synthesis of the Ligand}

Ethylenediamine bis dehydroacetic acid ligand $\left(\mathrm{H}_{2} \mathrm{~L}\right)$ was prepared by the condensation of ethylenediamene and dehydroacetic acid in 1:2 molar ratio respectively in absolute ethanol and refluxed on a water bath for three hours. The separated condensation product was filtered off, crystallized from absolute ethanol, and was finally dried in a vacuum desiccator over anhydrous calcium chloride.

\subsection{Synthesis of the Metal Complexes}

Metal complexes were prepared by mixed metal chloride and $\left(\mathrm{H}_{2} \mathrm{~L}\right)$ ligand in molar ratios (1:1) in absolute ethanol by adding the hot metal chloride solution [where metals are $\mathrm{Co}(\mathrm{II}), \mathrm{Ni}(\mathrm{II}), \mathrm{Cu}(\mathrm{II}), \mathrm{Fe}(\mathrm{II})$, and $\mathrm{Mn}(\mathrm{II})$ ] to the hot ligand solution. The mixture was cooled and the ammonia solution was added dropwise with shaking until $\mathrm{pH} 8$ was reached. The mixture was refluxed on a water bath for a time depending on the nature of the metal ion used. The complexes formed were filtered off, washed several times with pure dry ethanol, and vacuum-dried over anhydrous calcium chloride.

\section{Results and Discussion}

The ligand ethylenediamine bis dehydroacetic acid hydrazone $\left(\mathrm{H}_{2} \mathrm{~L}\right)$ was prepared from the condensation of dehydroacetic acid and ethylenediamine in the molar ratio of 2:1, respectively. All the new solid complexes of $\mathrm{Cu}(\mathrm{II}), \mathrm{Co}(\mathrm{II}), \mathrm{Ni}(\mathrm{II}), \mathrm{Fe}(\mathrm{III})$, and $\mathrm{Mn}(\mathrm{II})$ are stable in air and light. Thus, they are insoluble in most common organic solvents. The results of elemental analysis $(\mathrm{C}, \mathrm{H}, \mathrm{N})$ with molecular formula and melting points are in a good agreement with those calculated for the suggested formulas (Table 1). The molar conductance values indicated that all the complexes were good conductors. 


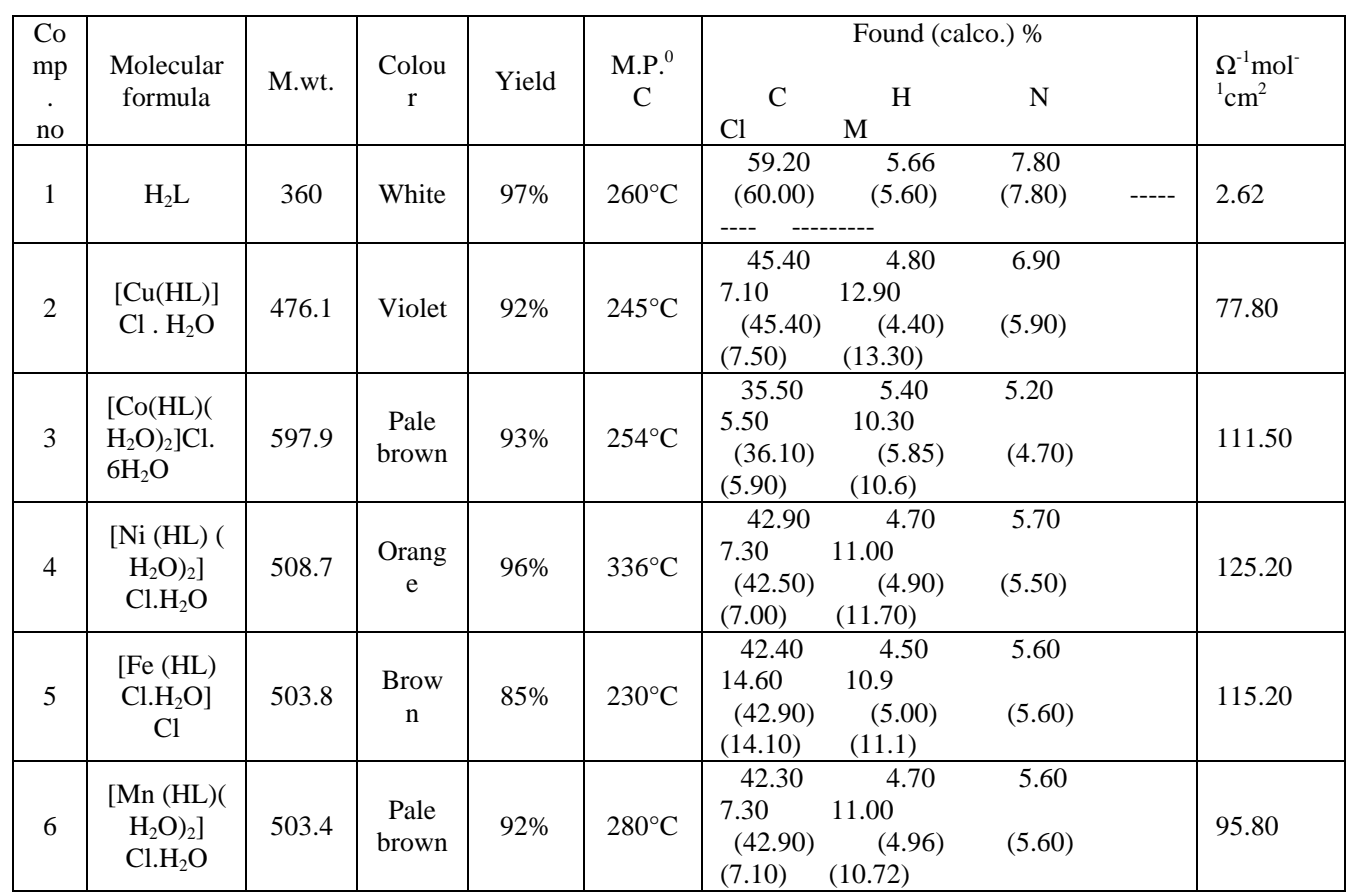

Table (1). Elemental analyses of the ligand $\left(\mathrm{H}_{2} \mathrm{~L}\right)$ and its complexes:

\section{1. ${ }^{1}$ HNMR Spectrum of the Ligand}

The ${ }^{1}$ HNMR spectrum of the free ligand $\left(\mathrm{H}_{2} \mathrm{~L}\right)$ in DMSO solution in Fig. (1) showed that the peak at $14 \mathrm{ppm}$ are assignable to the proton of $\mathrm{OH}$ group which disappeared in the presence of $\mathrm{D}_{2} \mathrm{O}$ as solvent (Gudasi, 2006). The protons of $\mathrm{CH}_{3}$ group of azomethine group and pyrone ring appeared as a singlet peak at 2.6 and $2.1 \mathrm{ppm}$, respectively (Chitrapriya, 2008). The peak at 3.9 and $3.4 \mathrm{ppm}$ corresponds to two $\mathrm{CH}_{2}$ groups of ethylenediamine. Also, the singlet peak at 5.7 ppm was assigned to the vinylic proton of DHA. 

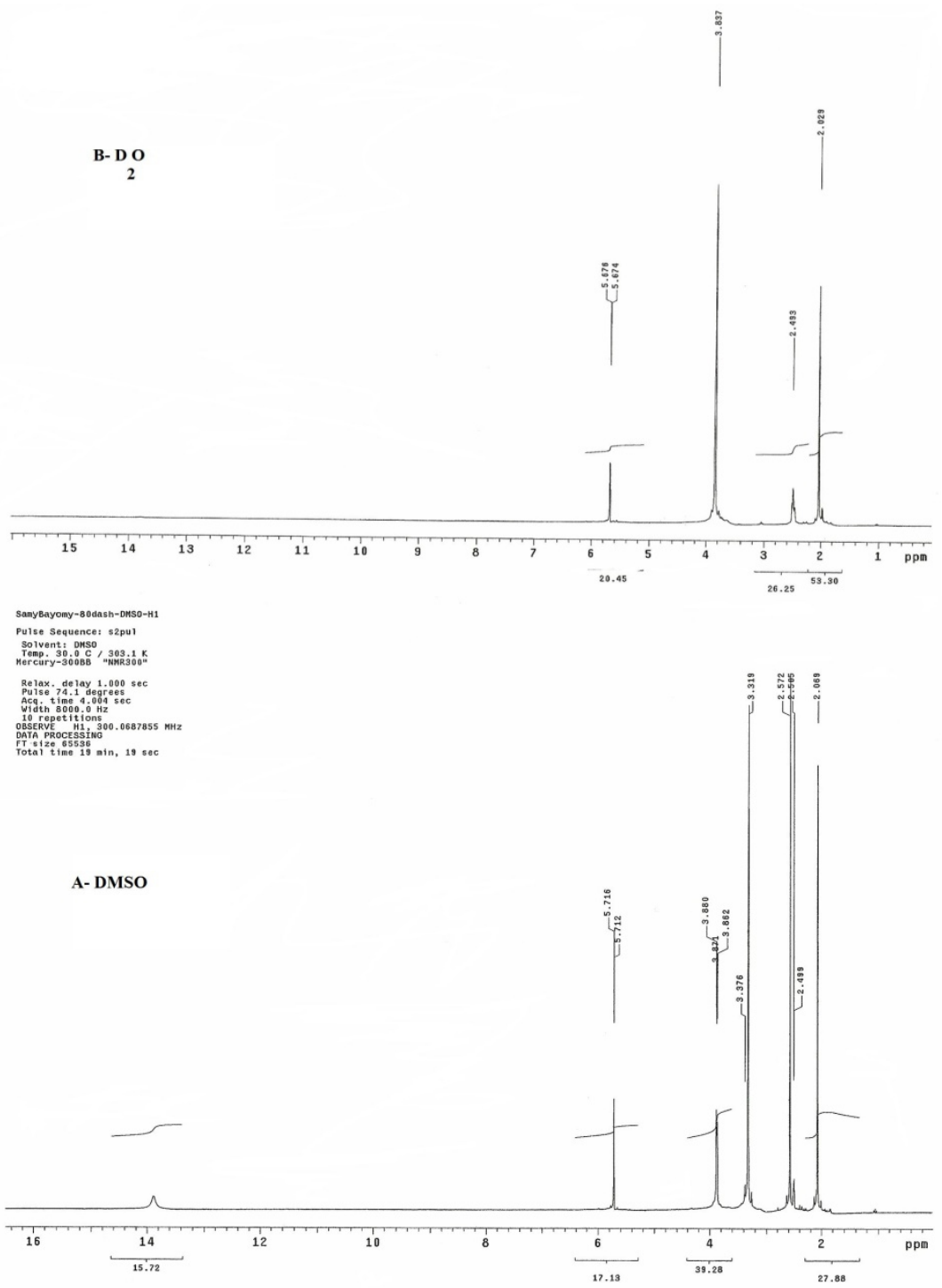

Fig (1). $\mathrm{H}^{1}$ NMR spectra of the ligand $\left(\mathrm{H}_{2} \mathrm{~L}\right)$ in A- DMSO and B- in the presence of $\mathrm{D}_{2} \mathrm{O}$

\subsection{Mass Spectrum of the Ligand}

Mass spectral data confirmed that the structure of the ligand $\left(\mathrm{H}_{2} \mathrm{~L}\right)$ was indicated by the peaks corresponding to their molecular mass as shown in Fig. (2). The appearance of the final peak at $\mathrm{m} / \mathrm{e}=360\left(\mathrm{C}_{18} \mathrm{H}_{20} \mathrm{~N}_{2} \mathrm{O}_{6}\right)$, equal the calculated molecular mass ( 360 ). Furthermore, other peaks at 193, 180, $166,151,138,109,85,81,67,55$, and 50 may be due to different fragments. However, the intensity of these peaks gives an idea of the stability of these fragments. 


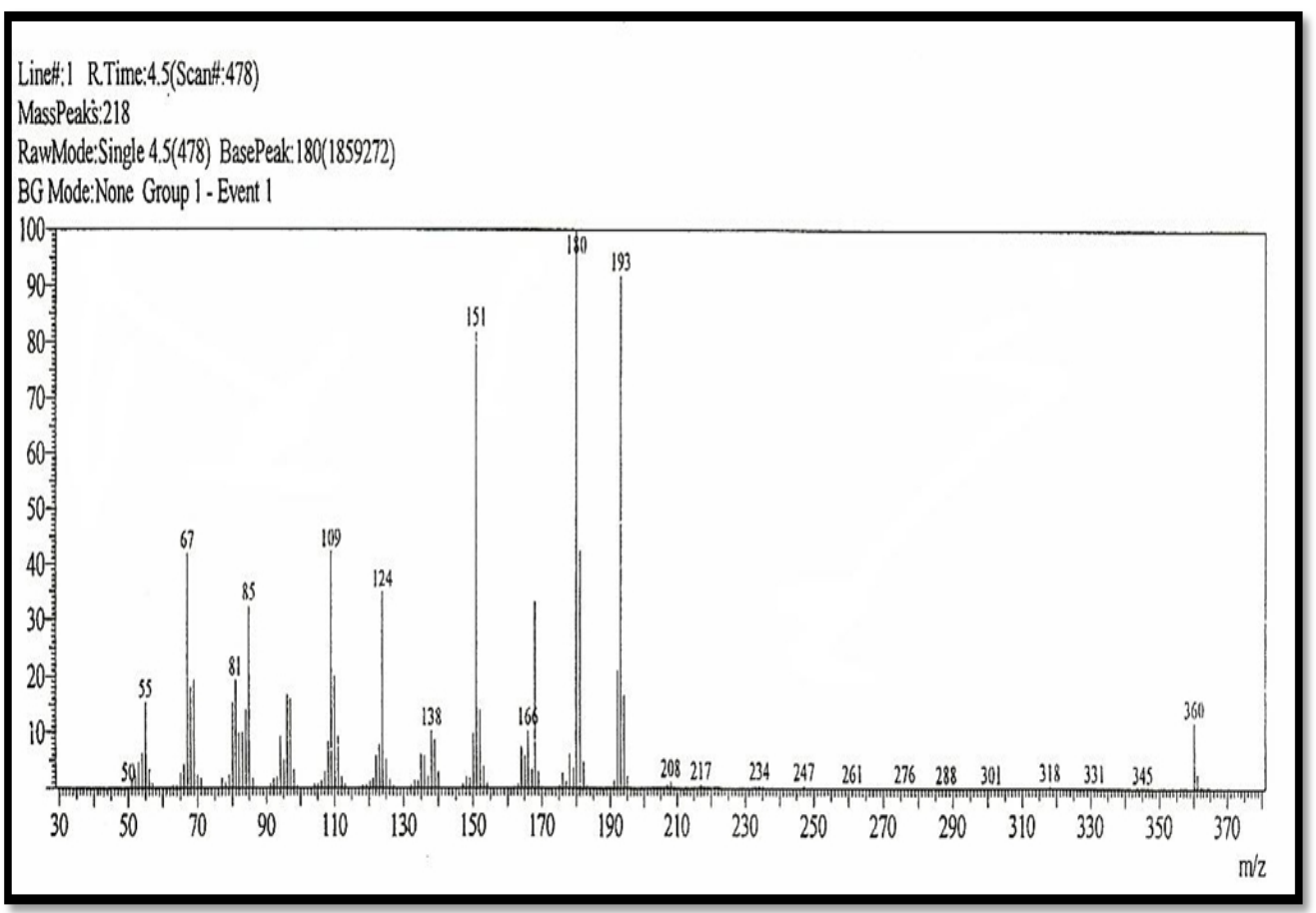

Fig.(2). Mass spectra of the ligand $\left(\mathrm{H}_{2} \mathrm{~L}\right)$

\subsection{IR Spectra}

The IR spectrum of the free ligand $\left(\mathrm{H}_{2} \mathrm{~L}\right)$ showed abroad band at 3430 $\mathrm{cm}^{-1}$ attributed to inter - and intra molecular hydrogen bonding $\mathrm{OH}$ group (Rigamonti, 2006 and Chalac, 2002). The spectrum also showed three strong bands at 1706, 1655, and $1566 \mathrm{~cm}^{-1}$ which are assigned to $\mathrm{vC}=\mathrm{O}$ (lactone), $v \mathrm{C}=\mathrm{O}$ (carbonyl) and $v \mathrm{C}=\mathrm{N}$, respectively (Chitrapriya, 2008). Therefore, this is depending on the above results and the elemental analyses (Table 2). The structure of ligand $\left(\mathrm{H}_{2} \mathrm{~L}\right)$ is shown in Scheme 1. The IR spectra of the complexes were compared with those of the free ligand in order to determine the coordination sites that may be involved in chelation and the position. Furthermore, the intensity of these peaks are expected to change upon chelation. In all the complexes, the peak of $v \mathrm{C}=\mathrm{O}$ (lactone) remains unaltered. The spectra also showed a broad band in the range of 3589-3000 $\mathrm{cm}^{-1}$, which suggested the presence of water molecules (Maihub, 2003; Srinivasan, 2004; El-Table, 2003; and Hegazy, 2001). Upon comparison, it was determined that the $v \mathrm{C}=\mathrm{O}$ and $v \mathrm{C}=\mathrm{N}$ stretching vibration is found in the free ligand at $1655-1566 \mathrm{~cm}^{-1}$. Thus, this was shifted to higher wave numbers in the complexes indicating the participation of the $v \mathrm{C}=\mathrm{O}$ and $\mathrm{vC}=\mathrm{N}$ in coordination (Ramarao, 1985 and Carugo, 1990). In all the complexes, the absence of the $v_{\mathrm{OH}}$ which appeared at $3400 \mathrm{~cm}^{-1}$ in the ligand, suggests the deprotonation of one phenolic oxygen prior to chelation (El-Table, 2002). 
New bands are found in the spectra of the complexes at 665-584 and 581$504 \mathrm{~cm}^{-1}$ which are assigned to $v \mathrm{M}-\mathrm{O}$ and $v \mathrm{M}-\mathrm{N}$ stretching vibrations (Robenson, 1973). In the spectrum of Fe(III) complex, the band of $v \mathrm{M}-\mathrm{Cl}$ appeared at $433 \mathrm{~cm}^{-1}$ (Kashar, 1998). Therefore, from the IR spectra of the complexes, we concluded that the ligand $\left(\mathrm{H}_{2} \mathrm{~L}\right)$ behaves as monobasic tetradentate, coordinated through $\mathrm{C}=\mathrm{O}$, deprotonated phenolic oxygen and the azomethine $\mathrm{N}$.<smiles>[3H]CCCN</smiles><smiles>CC1=CC(=O)C(C(C)=NCCN2[IH]Oc3oc(C)cc(=O)c3C2C)C(=O)O1</smiles><smiles>C=CCN=C(C)C1C(=O)C=C(C)OC1=O</smiles>

$\left(\mathrm{H}_{2} \mathbf{L}\right)$

\section{Scheme 1}




\begin{tabular}{|c|c|c|c|c|c|c|}
\hline $\begin{array}{c}\text { Comp. } \\
\text { no }\end{array}$ & Molecular formula & $v_{\mathrm{OH}}$ & $\begin{array}{c}v_{\mathrm{C}=\mathrm{O}} \\
\mathrm{DHA}\end{array}$ & $v_{\mathrm{C}=\mathrm{N}}$ & $v_{\mathrm{M}-\mathrm{O}}$ & $v_{\mathrm{M}-\mathrm{N}}$ \\
\hline 1 & $\mathrm{H}_{2} \mathrm{~L}^{3}$ & $3433(\mathrm{~m}, \mathrm{br})$ & $\begin{array}{c}1706(\mathrm{~s}) \\
1655(\mathrm{~s})\end{array}$ & $1566(\mathrm{~s})$ & -------- & ------- \\
\hline 2 & {$[\mathrm{Cu}(\mathrm{HL})] \mathrm{Cl} . \mathrm{H}_{2} \mathrm{O}$} & ---- & $\begin{array}{c}1681(\mathrm{~s}) \\
1640(\mathrm{w})\end{array}$ & $1579(\mathrm{~s})$ & $632(\mathrm{~m})$ & $526(\mathrm{~s})$ \\
\hline 3 & $\begin{array}{c}{[\mathrm{Co}(\mathrm{HL})(} \\
\left.\left.\mathrm{H}_{2} \mathrm{O}\right)_{2}\right] \mathrm{Cl} \cdot 6 \mathrm{H}_{2} \mathrm{O}\end{array}$ & ------- & $\begin{array}{c}1736(\mathrm{~s}) \\
1689(\mathrm{~s})\end{array}$ & $1643(\mathrm{~s})$ & $663(\mathrm{~m})$ & $582(\mathrm{~m})$ \\
\hline 4 & $\begin{array}{c}{\left[\mathrm{Ni}(\mathrm{HL})\left(\mathrm{H}_{2} \mathrm{O}\right)_{2}\right]} \\
\mathrm{Cl} \cdot \mathrm{H}_{2} \mathrm{O}\end{array}$ & ------- & $\begin{array}{c}1737(\mathrm{~s}) \\
1690(\mathrm{~s})\end{array}$ & $1644(\mathrm{~s})$ & $664(\mathrm{~m})$ & $581(\mathrm{~m})$ \\
\hline 5 & {$\left[\mathrm{Fe}(\mathrm{HL}) \mathrm{Cl} \cdot \mathrm{H}_{2} \mathrm{O}\right]$} & ------- & $\begin{array}{c}1696(\mathrm{~s}) \\
1642(\mathrm{~m})\end{array}$ & $1591(\mathrm{~s})$ & $621(\mathrm{Br})$ & $508(\mathrm{w})$ \\
\hline 6 & {$\left[\mathrm{Cl}(\mathrm{HL})\left(\mathrm{H}_{2} \mathrm{O}\right)_{2}\right]$} & ------- & $\begin{array}{c}1703(\mathrm{~s}) \\
1651(\mathrm{~s})\end{array}$ & $1568(\mathrm{~s})$ & $616(\mathrm{~s})$ & $507(\mathrm{~s})$ \\
\hline
\end{tabular}

Table (2). Important I.R. spectral of the ligand $\left(\mathrm{H}_{2} \mathrm{~L}\right)$ and its complexes br: broad m: medium w: week s: strong

\subsection{Electronic Spectra and Magnetic Moments}

The electronic obsorption spectrum of the ligand $\left(\mathrm{H}_{2} \mathrm{~L}\right)$ showed three bands with maxima at 412, 305, and $228 \mathrm{~nm}$ due to the various $n-\pi^{x}$ and $\pi-\pi^{x}$ transition (Kashar, 2010) (Table 3). The electronic spectra of the $\mathrm{Mn}(\mathrm{II})$ and Fe(III) complexes exhibited three bands at 640-610, 400.5 -380, and 310$311 \mathrm{~nm}$ which are assigned to ${ }^{6} \mathrm{~A}_{1 \mathrm{~g}} \quad{ }^{4} \mathrm{~T}_{1 \mathrm{~g}}(\mathrm{G}),{ }^{6} \mathrm{~A}_{1 \mathrm{~g}} \quad{ }^{4} \mathrm{~T}_{2 \mathrm{~g}}(\mathrm{G})$, and ${ }^{6} \mathrm{~A}_{1 \mathrm{~g}}$ ${ }^{4} \mathrm{E}_{1 \mathrm{~g}(\mathrm{G})}$ transition respectively indicating an octahedral configuration around the $\mathrm{Mn}(\mathrm{II})$ and $\mathrm{Fe}(\mathrm{III})$ ions (El-Table, 1999 and Afkar, 1994). The octahedral geometry was further confirmed by the value of the magnetic moment (5.8 $\left.\boldsymbol{\mu}_{\mathrm{B}}\right)$ for $\mathrm{Mn}(\mathrm{II})$ and $\left(5.9 \boldsymbol{\mu}_{\mathrm{B}}\right)$ for Fe(III). The electronic spectrum of the Co(II) complex exhibited three bands at 610, 471.5, and $316.5 \mathrm{~nm}$ which are assigned to ${ }^{4} \mathrm{~T}_{1 \mathrm{~g}}(\mathrm{~F})$ to ${ }^{4} \mathrm{~T}_{2 \mathrm{~g}}(\mathrm{~F}),{ }^{4} \mathrm{~T}_{1 \mathrm{~g}}(\mathrm{~F})$ to $4 \mathrm{~A}_{2 \mathrm{~g}}(\mathrm{~F})$, and ${ }^{4} \mathrm{~T}_{1 \mathrm{~g}}(\mathrm{~F})$ to ${ }^{4} \mathrm{~T}_{1 \mathrm{~g}}(\mathrm{P})$ transitions respectively indicating an octahedral configuration around the $\mathrm{Co}(\mathrm{II})$ ion. The magnetic moment for $\mathrm{Co}(\mathrm{II})$ complex was $4.5 \boldsymbol{\mu}_{\mathrm{B}}$ which is in good agreement with the reported values of an octahedral Co(II) complex (Afkar, 1994). The electronic spectrum of the Ni(II) complex shows three bands at $630,439.5$, and $338 \mathrm{~nm}$ which were assigned to the octahedral structure as well as the magnetic moment value $3.63 \mu_{\mathrm{B}}$ that support an octahedral geometry of the Ni(II) complex (Afkar, 1994). The copper complex showed different bands at 561, 308, and 252 suggesting square planar geometry (El-Saied, 2003 and Marina, 2004). The magnetic moment for the Copper(II) complex, 1.98 B.M., falls within the range normally observed for square - planar geometry (Lever and Lever, 1984). The electronic spectra of the complexes also shows bands below $400 \mathrm{~nm}$ which can be assigned to various types of intra $\pi-\pi^{*}$ and C.T. interactions. The bands of the $\pi-\pi *$ and $n-\pi *$ transitions of $\mathrm{C}=\mathrm{N}$ and $\mathrm{C}=\mathrm{O}$ bands have shown a blue shift due to the donation of lone pair of electrons to the metal ion that indicated the coordination of azomethine and carbonyl group with a reduction of intensity (Philip, 2006 and Kashar, 2011). 


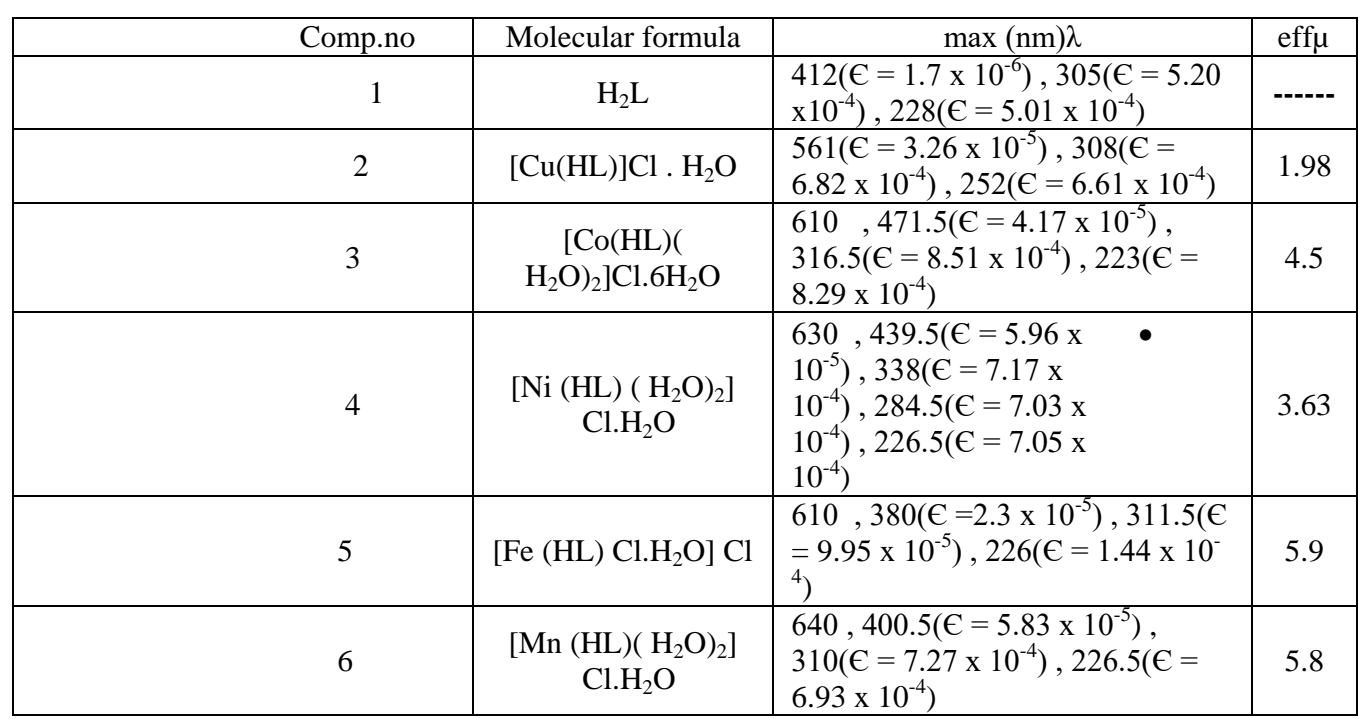

Table(3). Uv.Vis spectra of the ligand $\left(\mathrm{H}_{2} \mathrm{~L}\right)$ and its complexes

\subsection{X-ray Crystal Structure of the $[\mathrm{Cu}(\mathrm{HL})] \mathrm{Cl} . \mathrm{H}_{2} \mathrm{O}$ Complex}

The study of the crystal structure of the $[\mathrm{Cu}(\mathrm{HL})] \mathrm{Cl} . \mathrm{H}_{2} \mathrm{O}$ complex to establish its three dimensional structure geometry is shown in Table (5 and 6). There are two $[\mathrm{Cu}(\mathrm{HL})] \mathrm{Cl}_{2} \mathrm{H}_{2} \mathrm{O}$ molecules in each unit cell (Fig. 3). The $\mathrm{Cu}(\mathrm{II})$ was bonded to two oxygen and two nitrogen atoms from the ligand and the coordination geometry of $[\mathrm{Cu}(\mathrm{HL})] \mathrm{Cl} \cdot \mathrm{H}_{2} \mathrm{O}$ is best described as square planar with $\mathrm{N}_{2} \mathrm{O}_{2}$ occupying the four equatorial position. The ligand and $\mathrm{Cu}(\mathrm{II})$ ion form two six and one five chelate rings and the $\mathrm{Cu}(\mathrm{II})$ ion is at the center of the square planar. The water molecule and the chloride ion are at the outer sphere of the complex.

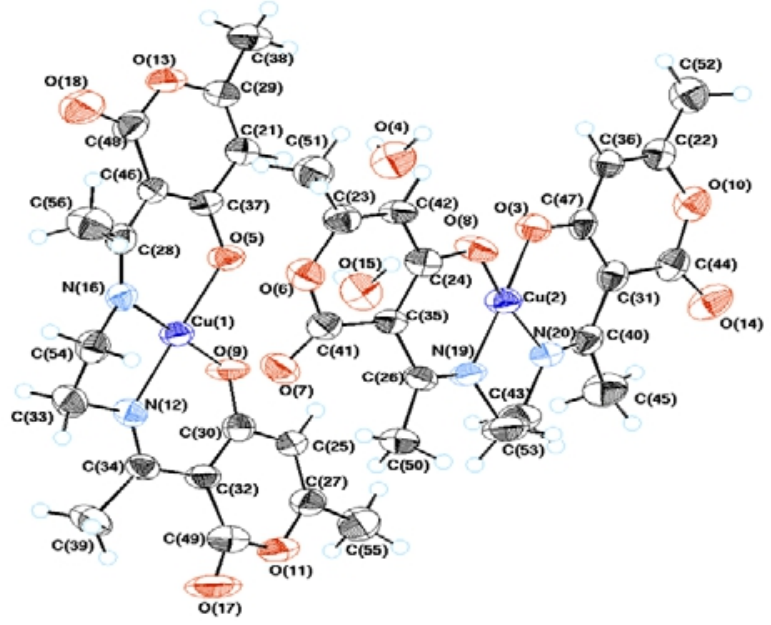

Fig.(3). Single crystal of the $[\mathrm{Cu}(\mathrm{HL})] \mathrm{Cl} . \mathrm{H}_{2} \mathrm{O}$ complex. 


\begin{tabular}{|c|c|}
\hline $\mathrm{C}_{36} \mathrm{H}_{44} \mathrm{Cu}_{2} \mathrm{~N}_{4} \mathrm{O}_{14} \mathrm{Cl}$ & $\mathrm{D}_{\mathrm{x}}=1.607 \mathrm{Mg} \mathrm{m}^{-3}$ \\
\hline $\mathrm{Z}=2$ & Density measured by: not measured \\
\hline $\mathrm{M}_{\mathrm{r}}=883.854$ & fine-focus sealed tube \\
\hline Triclinic & Mo $K \square$ radiation \\
\hline $\mathrm{P} \overline{1}$ & $\square=0.71073$ \\
\hline $\mathrm{a}=10.5907(3) \AA$ & Cell parameters from 5624 \\
\hline $\mathrm{b}=12.9430(4) \AA$ & $\square=2.910-27.485^{\circ}$ \\
\hline $\mathrm{c}=14.7847(6) \AA$ & $\square=1.24 \mathrm{~mm}^{-1}$ \\
\hline$\square=70.1677(12)^{\circ}$ & $\mathrm{T}=298 \mathrm{~K}^{\circ}$ \\
\hline$\square=89.0588(13)^{\circ}$ & Prismatic \\
\hline$\square=74.055(2)^{\circ}$ & Violet \\
\hline $\mathrm{V}=1826.46(11) \AA^{3}$ & Crystal source: Local laboratory \\
\hline $\mathrm{T}$
\end{tabular}

Table (4). X-ray crystal data of the $[\mathrm{Cu}(\mathrm{HL})] \mathrm{Cl} \cdot \mathrm{H}_{2} \mathrm{O}$ complex

\begin{tabular}{|c|c|c|c|c|c|}
\hline & $\mathrm{X}$ & $\mathrm{y}$ & $\mathrm{z}$ & $\mathrm{U}_{\mathrm{eq}}$ & Occ \\
\hline $\mathrm{Cu} 1$ & $0.33226(6)$ & $0.49583(5)$ & $0.55571(5)$ & $0.0383(4)$ & 1.00 \\
\hline $\mathrm{Cu} 2$ & $0.58054(6)$ & $0.06581(6)$ & $0.89711(5)$ & $0.0419(4)$ & 1.00 \\
\hline O3 & $0.6979(3)$ & $0.0708(3)$ & $0.9909(3)$ & $0.043(2)$ & 1.00 \\
\hline O4 & $0.6909(4)$ & $0.3098(3)$ & $0.9193(3)$ & $0.063(2)$ & 1.00 \\
\hline O5 & $0.4021(3)$ & $0.4881(3)$ & $0.6767(3)$ & $0.044(2)$ & 1.00 \\
\hline O6 & $0.1361(3)$ & $0.4215(3)$ & $0.7604(3)$ & $0.048(2)$ & 1.00 \\
\hline O7 & $0.1747(4)$ & $0.3635(3)$ & $0.6379(3)$ & $0.056(2)$ & 1.00 \\
\hline O8 & $0.4431(3)$ & $0.1713(3)$ & $0.9329(3)$ & $0.048(2)$ & 1.00 \\
\hline O9 & $0.4817(3)$ & $0.3722(3)$ & $0.5591(3)$ & $0.050(2)$ & 1.00 \\
\hline
\end{tabular}

Table (5). Selected Fractional atomic coordinates and equivalent isotropic thermal parameters ( $\AA^{2}$ of the $[\mathrm{Cu}(\mathrm{HL})] \mathrm{Cl} . \mathrm{H}_{2} \mathrm{O}$ complex)

$$
U_{e q}=1 / 3 \square_{i} \square_{j} U_{i j} a_{i}{ }^{*} a_{j}{ }^{*} \boldsymbol{a}_{i} \cdot \boldsymbol{a}_{j}
$$

\begin{tabular}{|c|c|c|c|c|c|c|}
\hline & $\mathrm{U}_{11}$ & $\mathrm{U}_{12}$ & $\mathrm{U}_{13}$ & $\mathrm{U}_{22}$ & $\mathrm{U}_{23}$ & $\mathrm{U}_{33}$ \\
\hline $\mathrm{Cu} 1$ & $0.0380(4)$ & $-0.0029(3)$ & $-0.0063(3)$ & $0.0310(4)$ & $-0.0160(3)$ & $0.0376(4)$ \\
\hline $\mathrm{Cu} 2$ & $0.0383(4)$ & $-0.0043(3)$ & $-0.0009(3)$ & $0.0386(4)$ & $-0.0202(3)$ & $0.0403(4)$ \\
\hline O3 & $0.042(2)$ & $0.0039(19)$ & $-0.0079(18)$ & $0.034(2)$ & $-0.0156(18)$ & $0.041(2)$ \\
\hline O4 & $0.043(2)$ & $-0.003(2)$ & $0.002(2)$ & $0.056(3)$ & $-0.027(2)$ & $0.075(3)$ \\
\hline O5 & $0.044(2)$ & $0.0008(18)$ & $-0.0099(18)$ & $0.035(2)$ & $-0.0199(19)$ & $0.044(2)$ \\
\hline O6 & $0.042(2)$ & $-0.0022(19)$ & $-0.0003(19)$ & $0.046(2)$ & $-0.016(2)$ & $0.044(2)$ \\
\hline O7 & $0.058(3)$ & $-0.012(2)$ & $-0.006(2)$ & $0.058(3)$ & $-0.015(2)$ & $0.038(2)$ \\
\hline O8 & $0.035(2)$ & $0.003(2)$ & $-0.0062(18)$ & $0.058(3)$ & $-0.027(2)$ & $0.039(2)$ \\
\hline
\end{tabular}

Table (6). Selected anisotropic displacement parameters $\left(\AA^{2}\right.$ of the $[\mathrm{Cu}(\mathrm{HL})] \mathrm{Cl} \cdot \mathrm{H}_{2} \mathrm{O}$ complex)

\subsection{TGA, DTA and DTG of the Ligand $\left(\mathrm{H}_{2} \mathrm{~L}\right)$ and their Complexes}

The thermogram of the ligand remains constant up to $152{ }^{\circ} \mathrm{C}$ which indicates that it is thermally stable in air and light, and the decomposition proceeds without melting in two steps with weight loss of $55.2 \%$ at 152 $414{ }^{\circ} \mathrm{C}$. This may be due to the loss of $\mathrm{C}_{10} \mathrm{H}_{12} \mathrm{NO}_{3}$ as $\mathrm{CO}_{2}$ and $\mathrm{NO}_{2}$ gases at 414-600 ${ }^{\circ} \mathrm{C}$ with weight loss of $41.94 \%$ due to loss of $\mathrm{C}_{7} \mathrm{H}_{4} \mathrm{NO}_{3}$. Thus, this loss appeared as endothermic peaks in DTA. The TG curves of $\mathrm{Cu}(\mathrm{II})$ and 
Co(II) complexes showed an endothermic peak at 120 and $(72,116)^{\circ} \mathrm{C}$ due to the loss of crystalline water (Venkatachalam, 2005). The $\mathrm{HCl}$ molecule was liberated at a temperature above $300{ }^{\circ} \mathrm{C}$ (Kumar, 2007). The product is stable up to $500^{\circ} \mathrm{C}$. The organic constituents of the complexes start decomposing leading to the decomposition products at $550-600^{\circ} \mathrm{C}$ (Chalaca, 2002 and Sivagamasundari, 2007).

The thermal decomposition of all the complexes was found to take place through four steps. The first was the dehydration of the complexes followed by the elimination of the chloride anion, as hydrochloric acid molecule, in the second step. The third and the fourth steps intermingled together in most cases in which the anhydrous anion free complex underwent decomposition to the metal oxide (MO) through the loss of the organic part as $\mathrm{CO}_{2}$. The metal contents were calculated from the residue and were found to be in good agreement with the results of the elemental analyses. Therefore, the four steps of the thermal decomposition can be represented as follows:

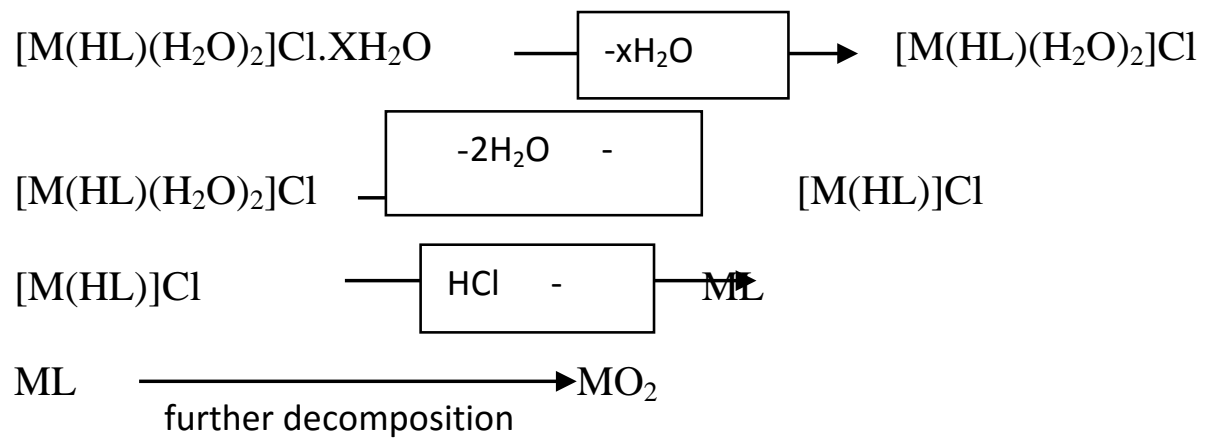

\section{Conclusion}

Dehydroacetic acid hydrazone and their complexes have been prepared. The molecular structures of the resulted complexes are evaluated by physicochemical analyses. The IR spectra showed that the ligand $\left(\mathrm{H}_{2} \mathrm{~L}\right)$ behaves as monobasic tetradentate ligand coordinating through $\mathrm{C}=\mathrm{O}$, deprotonated phenolic oxygen, and the azomethine $\mathrm{N}$. The crystal structure of the $[\mathrm{Cu}(\mathrm{HL})] \mathrm{Cl} . \mathrm{H}_{2} \mathrm{O}$ complex has been established and convoluted that the ligand and $\mathrm{Cu}(\mathrm{II})$ ion formed a two six and one five chelate rings. All the complexes have octahedral geometry, but the $[\mathrm{Cu}(\mathrm{HL})] \mathrm{Cl} . \mathrm{H}_{2} \mathrm{O}$ complex has square planar geometry. In addition, the thermal decomposition of the complexes was found to take place through four steps.

\section{References:}

M.Z. Chalaca, J.D. Figueroa-Villar, R.A. Ellena and E.E. Castellano, Inorg. Chim. Acta ,328, 2002, 45-52. 
S.S.Lim,H.S.Kim,D.U.Lee, Bull.Korean Chem.Soc.28 ,2495,2007,2495.

M.S.Ponnurengam,S.Malliappan,K.G.Sethu,M.Doble,.Pharm.Bull.55,2007,4 4.

G.S.B.Viana,M.A.M.Bandeira,F.J.A.Matos,Phytomedicine,10,189,2003, 189.

S.J.Won,C.T.Liu,L.T.Tsao,J.R.Weng,H.H.Ko,J.P.Wang,C.N.Lin,Eur.J.Med. Chem.40,2005,103.

S. F. Tan, K. P. Ang , H. L. Jayachandran, J.Trans.Met. Chem., 9,1984, (390-395).

F. A. El-Saied, A. A. El-Asmy, W. Kaminsky , D. X. West, J. Trans. Met Chem., 28, 2003, (954-960).

C. Marina , V. Visnja , N. T. Kajfez , C. Manda , B. Ana ,K. Boris, J. Molecular Structure,701, 2004, (111-118).

G. Venkatachalam, R. Ramesh ,J.Tetrahedron Lett., 46 , 2005, 5215.

K. N. Kumar, R. Ramesh, Y. Liu, J. Mol. Catal. A: Chem., 265, 2007,218.

S. Kannan, R. Ramesh, Y. Liu ,J. Organomet. Chem. 692, 2007 ,3380.

M. Sivagamasundari, R. Ramesh, J. Spectrochim. Acta Part A 66, 2007, 427-433.

A.S. El-Tabl ,Transition Met. Chem., 21,1996, 428.

K.B. Gudasi, S.a patil, R.S. Vadvavi, R.V Shenoy, M. Nthaji, Trans. Met. Chem. 31 ,2006, 586-592.

N. Chitrapriya, V. Mahalingam, M. Zeller, R. Jayabalan, K. Swaminathan, K. Natarajan , Polyhedron, 27(26 ), 2008, (939-946).

L. Rigamonti, F. Demartin, A. Forni, S. Righetto, A.Pasini ,Inorg. Chem., 45,2006, 10976.

M.Z.Chalac,J.D.F.Villar,J.A.Ellena,E.E.Castellano,Inorg.Chim.Acta, $\quad 45$, 2002, 328.

A.A.Maihub, M.M.EL-ajaily, M.M. Aboukrish and A.I. Salem,7(2), 41-47, 2003.

R. Srinivasan, I. Sougandi, K. Velavan, R. Venkatesan, V. Babu, P.S. Rao; Polyhedron 23, 2004,1115.

A.S.El-Table,K.El-Baradie,R.M.Issa, J.Coord.Chem.56 ,2003,1113.

W.H.Hegazy,Monat.For Chem..132,2001, 639.

N.Ramarao,V.P.Rao,V.J.TyagaRaju,M.C.Ganorkar,Indian

J.Chem.A24,877,1985.

O.Carugo,C.B.Castellani,M.Rizzi,Polyhedron 9,2061,1990.

A.S.El-Table,J.Chem.Res.529.2002.

S.D.Robenson,M.F.Uttly,J.Chem.Soc.1912,1973

T.I. Kashar, A.S. EI-Tabl, R.M. EI-bahnasawy, J. Polish J. Chem., 72, 1998, (2037-2044).

T.I.Kashar ,Thermochimica acta ,507, 2010, 66-70 . 
A.S.El-Table,T.I.Kashar,R.M.El-Bahnasawy,A.El-Monsef

Ibrahem, Pol.J.Chem.73,1999, ,245.

K.A.H.Afkar,IndianJ.Chem.A33,879,1994.

A.B.P.Lever,Inorganicelectronicspectroscopy,Elsevier,Amsterdam,1968.

A.B.P. Lever " Inorganic Electronic Spectroscopy" Elsevier Amest.2nd edit. 1984.

V. Philip, V. Suni, M.R.P. Kurup; M.Nethaji, Polyhedron 25 ,2006, 1931. T.I.Kashar,A.M.EL-Nahas,A.M.EL-Maughamsi , Asian Journal of Chemistry; 23 , 2011, 159-165.

\begin{tabular}{|c|l|l|l|}
\hline $\mathrm{Cu} 1-\mathrm{O} 5$ & $1.908(2)$ & $\mathrm{O} 10-\mathrm{O} 14$ & $2.165(3)$ \\
\hline $\mathrm{Cu} 1-\mathrm{O} 7$ & $2.699(2)$ & $\mathrm{O} 10-\mathrm{C} 22$ & $1.367(3)$ \\
\hline $\mathrm{Cu} 1-\mathrm{O} 9$ & $1.904(2)$ & $\mathrm{O} 10-\mathrm{C} 31$ & $2.422(3)$ \\
\hline $\mathrm{Cu} 1-\mathrm{N} 12$ & $1.938(2)$ & $\mathrm{O} 10-\mathrm{C} 36$ & $2.340(3)$ \\
\hline $\mathrm{Cu} 1-\mathrm{N} 16$ & $1.942(2)$ & $\mathrm{O} 10-\mathrm{C} 44$ & $1.378(3)$ \\
\hline $\mathrm{Cu} 2-\mathrm{O} 3$ & $1.906(2)$ & $\mathrm{O} 10-\mathrm{C} 52$ & $2.354(4)$ \\
\hline $\mathrm{Cu} 2-\mathrm{O} 8$ & $1.907(2)$ & $\mathrm{O} 11-\mathrm{O} 17$ & $2.183(3)$ \\
\hline $\mathrm{Cu} 2-\mathrm{O} 15$ & $2.712(2)$ & $\mathrm{O} 11-\mathrm{C} 25$ & $2.332(3)$ \\
\hline $\mathrm{Cu} 2-\mathrm{N} 19$ & $1.926(2)$ & $\mathrm{O} 11-\mathrm{C} 27$ & $1.356(3)$ \\
\hline $\mathrm{Cu} 2-\mathrm{N} 20$ & $1.933(2)$ & $\mathrm{O} 11-\mathrm{C} 32$ & $2.444(3)$ \\
\hline O3-O8 & $2.664(2)$ & $\mathrm{O} 11-\mathrm{C} 49$ & $1.399(3)$ \\
\hline O3-C31 & $2.398(3)$ & $\mathrm{O} 11-\mathrm{C} 55$ & $2.366(3)$ \\
\hline O3-C36 & $2.307(3)$ & $\mathrm{N} 12-\mathrm{N} 16$ & $2.690(3)$ \\
\hline O3-C47 & $1.287(3)$ & $\mathrm{N} 12-\mathrm{C} 32$ & $2.393(3)$ \\
\hline O5-O9 & $2.649(3)$ & $\mathrm{N} 12-\mathrm{C} 33$ & $1.468(3)$ \\
\hline
\end{tabular}

Table (7). Selected geometric parameters $\left(\AA,^{\circ}\right)$ of the $[\mathrm{Cu}(\mathrm{HL})] \mathrm{Cl} \cdot \mathrm{H}_{2} \mathrm{O}$ complex 


\begin{tabular}{|c|c|c|c|c|c|c|c|c|}
\hline \multirow{3}{*}{$\begin{array}{c}\text { Comp } \\
\text { no }\end{array}$} & \multirow{3}{*}{ Molecular formula } & \multirow{3}{*}{$\mathbf{n}^{*}$} & \multicolumn{2}{|c|}{ DTA Peaks } & \multicolumn{3}{|c|}{ TGA Peaks } & \multirow{3}{*}{ Assignment } \\
\hline & & & \multirow{2}{*}{$\underset{C^{\circ}}{\text { Temp }}$} & \multirow{2}{*}{ Peak } & \multirow{2}{*}{$\underset{C^{\circ}}{\text { Temp }}$} & \multicolumn{2}{|c|}{ Wt. Loss\% } & \\
\hline & & & & & & Calcd. & Found & \\
\hline 1 & $\mathrm{H}_{2} \mathrm{~L}$ & $\begin{array}{l}6 \\
1\end{array}$ & $\begin{array}{l}257 \\
498\end{array}$ & $\begin{array}{l}\text { Endo. } \\
\text { Exo. }\end{array}$ & $\begin{array}{l}152-414 \\
414-600\end{array}$ & $\begin{array}{l}53.9 \\
41.7\end{array}$ & $\begin{array}{l}55.27 \\
41.94\end{array}$ & $\begin{array}{l}\text { Loss of } \\
\left(\mathrm{C}_{10} \mathrm{H}_{12} \mathrm{NO}_{3}\right) \text { as } \\
\left(\mathrm{CO}_{2} \text { and } \mathrm{NO}_{2}\right) . \\
\text { Loss of } \\
\left(\mathrm{C}_{7} \mathrm{H}_{4} \mathrm{NO}_{3}\right) .\end{array}$ \\
\hline 2 & {$[\mathrm{Cu}(\mathrm{HL})] \mathrm{Cl} . \mathrm{H}_{2} \mathrm{O}$} & $\begin{array}{l}1 \\
1 \\
1 \\
1\end{array}$ & $\begin{array}{l}120 \\
204 \\
315 \\
454\end{array}$ & $\begin{array}{l}\text { Endo. } \\
\text { Endo. } \\
\text { Exo. } \\
\text { Exo. }\end{array}$ & $\begin{array}{c}78.144 \\
144-226 \\
226-380 \\
380-560\end{array}$ & $\begin{array}{c}3.7 \\
7.7 \\
35.1\end{array}$ & $\begin{array}{c}3.7 \\
7.2 \\
35.8 \\
39.9\end{array}$ & $\begin{array}{l}\text { Loss of one } \\
\text { lattice water. } \\
\text { Loss of } \mathrm{HCl} \text {. } \\
\text { Loss of } \\
\left(\mathrm{C}_{8} \mathrm{H}_{9} \mathrm{NO}_{3}\right) \text { as } \\
\left(\mathrm{CO}_{2} \text { and } \mathrm{NO}_{2}\right) \\
\text { Further } \\
\text { decomposition. }\end{array}$ \\
\hline 3 & {$\left[\mathrm{Co}(\mathrm{HL})\left(\mathrm{H}_{2} \mathrm{O}\right)_{2}\right] \mathrm{Cl} .6 \mathrm{H}_{2} \mathrm{O}$} & $\begin{array}{l}1 \\
3 \\
4 \\
1\end{array}$ & $\begin{array}{c}72 \\
116,225 \\
430 \\
553\end{array}$ & $\begin{array}{c}\text { Endo. } \\
\text { Endo. } \\
\text { Exo. } \\
\text { Exo. }\end{array}$ & $\begin{array}{c}47-86 \\
86-227 \\
227-436 \\
436-580\end{array}$ & $\begin{array}{c}3.00 \\
12.00 \\
24.7\end{array}$ & $\begin{array}{c}2.9 \\
13.3 \\
24.7 \\
37.7\end{array}$ & $\begin{array}{l}\text { Loss of one } \\
\quad \text { lattice water. } \\
\text { Loss of four } \\
\text { lattice water. } \\
\text { Loss of one } \\
\text { lattice and two } \\
\text { coordinate } \\
\text { water, } \mathrm{H} \mathrm{Cl}, \mathrm{CH}_{3} \\
\text { andCO }{ }_{2} \text {. } \\
\text { Further } \\
\text { decomposition. }\end{array}$ \\
\hline 4 & $\begin{array}{l}{[\mathrm{Ni}(\mathrm{HL})(} \\
\left.\left.\mathrm{H}_{2} \mathrm{O}\right)_{2}\right] \mathrm{Cl} . \mathrm{H}_{2} \mathrm{O}\end{array}$ & $\begin{array}{l}1 \\
2 \\
1\end{array}$ & $\begin{array}{l}329 \\
415\end{array}$ & $\begin{array}{l}\text { Endo. } \\
\text { Exo. }\end{array}$ & $\begin{array}{c}68-203 \\
266-417 \\
417-482\end{array}$ & $\begin{array}{c}3.4 \\
33.5\end{array}$ & $\begin{array}{c}3.8 \\
35.5\end{array}$ & $\begin{array}{l}\text { Loss of one } \\
\text { lattice water. } \\
\text { Loss of two } \\
\text { coordinated } \\
\text { water and } \mathrm{CO}_{2} \text {. } \\
\text { Further } \\
\text { decomposition. }\end{array}$ \\
\hline 5 & {$\left[\mathrm{Fe}(\mathrm{HL}) \mathrm{Cl} . \mathrm{H}_{2} \mathrm{O}\right] \mathrm{Cl}$} & $\begin{array}{l}1 \\
3 \\
3\end{array}$ & $\begin{array}{l}238 \\
485 \\
538\end{array}$ & $\begin{array}{l}\text { Exo. } \\
\text { Exo. } \\
\text { Exo. }\end{array}$ & $\begin{array}{c}38-119 \\
119-391 \\
391-592\end{array}$ & $\begin{array}{c}3.5 \\
23.7\end{array}$ & $\begin{array}{c}4.75 \\
23.82 \\
15.31\end{array}$ & $\begin{array}{r}\text { Loss of one } \\
\text { coordinated } \\
\text { water. } \\
\text { Loss of } \mathrm{Cl}_{2} \text { and } \\
\mathrm{CO}_{2} . \\
\text { Further } \\
\text { decomposition. }\end{array}$ \\
\hline 6 & $\begin{array}{l}{\left[\mathrm{Mn}(\mathrm{HL})\left(\mathrm{H}_{2} \mathrm{O}\right)_{2}\right]} \\
\mathrm{Cl} \cdot \mathrm{H}_{2} \mathrm{O}\end{array}$ & $\begin{array}{l}2 \\
2 \\
1 \\
3\end{array}$ & $\begin{array}{l}264 \\
368 \\
416 \\
454 \\
556\end{array}$ & $\begin{array}{l}\text { Exo. } \\
\text { Exo. } \\
\text { Exo. } \\
\text { Exo. } \\
\text { Exo. }\end{array}$ & $\begin{array}{l}119-212 \\
212-279 \\
279-375 \\
375-583\end{array}$ & $\begin{array}{c}7.3 \\
10.7 \\
17.5\end{array}$ & $\begin{array}{c}7.9 \\
11.9 \\
16.2 \\
43.0\end{array}$ & $\begin{array}{l}\text { Loss of one } \\
\text { lattice and one } \\
\text { coordinated } \\
\text { water. } \\
\text { Loss of one } \\
\text { coordinated } \\
\text { water and } \mathrm{HCl} \\
\text { Loss of } 2\left(\mathrm{CO}_{2}\right) \text {. } \\
\text { Further } \\
\text { decomposition. }\end{array}$ \\
\hline
\end{tabular}

$\mathrm{n}^{*}$. number of stages of decomposition $\quad$ Endo. Endothermic peak $\quad$ Exo. Exothermic peak Table (8): Thermal analysis of the ligand $\left(\mathrm{H}_{2} \mathrm{~L}\right)$ and its metal complexes 